\title{
EVALUATION OF LEVEL OF EFFECTIVENESS AND EFFICIENCY IN VILLAGE FUND MANAGEMENT ACCORDING TO THE REGULATION OF THE MINISTER OF NUMBER 16 OF 2018 IN KOLONGAN-TETEMPANGAN VILLAGE
}

\author{
Maykel. A. Tampenawas, Raymond. F. Rombot, Denny I. Y. Rompas, Deisy Lusiana \\ Department Of Accounting, Polytechnic of Manado Country \\ DOI: $10.31364 /$ SCIRJ/v7.i10.2019.P1019713 \\ http://dx.doi.org/10.31364/SCIRJ/v7.i10.2019.P1019713
}

\begin{abstract}
The purpose of this research was to determine the level of effectiveness and efficiency of village fund management in Kolongan Tetempangan Village. This type of research is descriptive research. Data collection method used is the case method. The data collection conducted in this research, namely by collecting information relating to the effectiveness, and efficiency of village fund management that occurred in the Kolongan Tetempangan village for a period of three years, from 2016 to 2018. The analytical tool used is the ratio effectiveness and efficiency ratio. The results showed that the level of effectiveness of village fund management, in Kolongan Tetempangan Village was at the level of effective management. Meanwhile, the level of efficiency in managing village funds is also at an efficient level.
\end{abstract}

Keywords: Effectiveness, Efficiency, Funds

\section{INTRODUCTION}

The enactment of Law No. 6 of 2014 concerning Villages, has a fundamental impact on changes in the position and relations between villages and regions and the government which includes: aspects of authority, planning, development, finance and village democracy will be stronger. With the enactment of Law No. 6 of 2014 concerning Villages, the village is given a great opportunity to manage its own governance autonomously and carry out development to improve the welfare and quality of life of the people in the village. In addition, the village government is expected to be more independent in running and managing the government with a variety of natural resources owned, including financial management and village property. Law No. 6 of 2014 concerning Villages clearly states that villages and adat villages receive the same treatment from the central government and regional governments. In this case, the village is given autonomy to regulate and manage the interests of the community based on the rights of origin, customs and socio-cultural values of the community, the village as well as establishing and managing village institutions. Of course, to run all of that the village government needs funds so that various programs and policies can be carried out according to plan.

As for the financial assistance, it is obtained from sources of village income which include Village Original Income, the allocation of the State Expenditure Budget, part of Regional Taxes and Regional Levies for districts / cities, Village Fund Allocation, financial assistance from the Village Budget and Revenue provincial / district / city, grants and third party donations and other legal income. The existence of these assistance policies, aims so that the village government can provide excellent services by empowering the community to actively participate in development activities programs, both physical and non-physical so that development is achieved and improving the welfare of village communities.

In order to achieve these goals, since 2015 the government has provided and channeled Village Fund assistance to all villages sourced from the Budget Revenue and State Expenditures. However, as part of the Unitary State of the Republic of Indonesia, the village government needs to receive supervision from the government level above it. This is because, in the future the amount of Village Funds that will be given to villages will be even greater, while the capacity and capability of Human Resources in managing village finances is still inadequate. In addition, community involvement to plan for and oversee the use of the Village Fund. As such, this becomes a duty and an important note, not only for the central government but also for district / city governments and village governments, as well as the community to develop villages collectively. All sets of laws and regulations relating to the village, so that 
the management of village funds runs on a corridor that is correct, clear, transparent and accountable, so as to produce an efficient process and achieve effective results. Village Funds are funds sourced from the Budget Revenue and State Expenditures which are destined for villages and are used to finance governance, implementation of development, community development and community empowerment.

From preliminary observations, information is obtained that shows the classic problems that are often faced by village governments, namely the inadequacy of Human Resources, in village government officials, in managing village funds / finance effectively, and efficiently, especially in terms of the use of village funds. This phenomenon is indicated in the KolonganTetempangan Village, Kalawat District which is the place for research locations. Based on the description above, researchers are interested in conducting research in the Kolongan Tetempangan Village in evaluating the management of effective and efficient village funds by the existing apparatus, whether they are appropriate, or not according to the Minister of Village Regulation No. 16 of 2018 in order to support the village autonomy program.

\section{RESEARCH METHODS}

The research method uses qualitative methods, where this method focuses more on the pattern of Village Fund management activities, carried out by the village government, through the Village Financial Management Technical Implementer, the village apparatus appointed by the Village Head in carrying out village financial management. The approach used in this research is to explore, and describe the conditions factually in the field, according to applicable scientific norms and norms. Therefore, this research will require interaction between researchers who are interactive with the object of research to understand the reality that occurs (Musianto, 2002).

2.1. Measures of Effectiveness and Efficiency

\begin{tabular}{|c|l|l|}
\hline 1. & $\left\{\frac{\text { Actual Output }}{\text { Target Output }}\right\} \geq 1$ & $\begin{array}{l}\text { If the result of comparing the actual output with the target } \\
\text { output } \geq 1, \text { effectiveness is achieved. }\end{array}$ \\
\hline 2. & $\left\{\frac{\text { Actual Output }}{\text { Target Output }}\right\}<1$ & $\begin{array}{l}\text { If the results of comparison of actual output with target } \\
\text { output }<1 \text { then effectiveness is not achieved. }\end{array}$ \\
\hline
\end{tabular}

In this study, the effectiveness is aimed at measuring the effectiveness of the management of village funds, by comparing the realization of revenue with a budget whose formula is as follows:

$$
\text { Effectiveness }=\frac{\text { Realization }}{\text { Budget }(\text { Target })} \times 100 \%
$$

The above effectiveness formula has a measure with standard criteria based on Decree of the Minister of the Interior No. 690,900-237 of 1996 concerning the evaluation criteria, and financial performance in this case the management of village funds, where the size of these criteria can be seen in the following table.

Table 2.1. Level of Effectiveness Criteria

\begin{tabular}{|c|c|}
\hline Criteria & Percentage \\
\hline Very Effective & $>100 \%$ \\
\hline Effective & $90 \%-100 \%$ \\
\hline Quite Effective & $80 \%-90 \%$ \\
\hline Less Effective & $60 \%-80 \%$ \\
\hline Ineffective & $0-60 \%$ \\
\hline
\end{tabular}

Source: Ministry of Home Affairs, 2019

The lower the efficiency ratio, the better the results, and vice versa. To analyze the level of efficiency is done using the following formula:

$$
\text { Efficiency }=\frac{\text { Realized Use (Expenditures) }}{\text { Realized Revenue }} \times 100 \%
$$


The above efficiency formula has a standard criteria based on the Minister of Home Affairs Decree No. 690,900-237 of 1996 concerning evaluation criteria, and financial performance. In this case, the management of village funds where the size of these criteria can be seen in the following table.

Table 2.2. Efficiency Level Criteria

\begin{tabular}{|c|c|}
\hline Criteria & Percentage \\
\hline Inefficient & $>100 \%$ \\
\hline Less Efficient & $90 \%-100 \%$ \\
\hline Quite Efficient & $80 \%-90 \%$ \\
\hline Efficient & $60 \%-80 \%$ \\
\hline Very Efficient & $0-60 \%$ \\
\hline
\end{tabular}

Source: Ministry of Home Affairs, 2019

III. DISCUSSION

Table 3.1. Population Data by Education Level

\begin{tabular}{|c|c|c|}
\hline Number & Education Level & Number (Soul) \\
\hline 1 & Kindergarten / Non-school & 527 \\
\hline 2 & Not graduated from elementary school & 48 \\
\hline 3 & Elementary school & 659 \\
\hline 4 & Middle School & 589 \\
\hline 5 & High Schools & 1.593 \\
\hline 6 & Diploma 1 & 8 \\
\hline 7 & Diploma 2 & - \\
\hline 8 & Diploma 3 & 41 \\
\hline 9 & Diploma 4 & 323 \\
\hline 10 & Strata 1 & 35 \\
\hline 11 & Strata 2 & - \\
\hline 12 & Strata 3 & 3.828 \\
\hline
\end{tabular}

Data Source: Village government, Kolongan Tetempangan, 2019

Table 3.2. Population Data According to Religious Groups

\begin{tabular}{|c|c|c|}
\hline \multirow{2}{*}{ Number } & Religion & Number (Soul) \\
\hline 1 & Christian & 3.260 \\
\hline 2 & Catholics & 221 \\
\hline 3 & Islam & 344 \\
\hline 4 & Buddha & 3 \\
\hline 5 & Hindus & - \\
\hline & Total & 3.828 \\
\hline
\end{tabular}

Data Source: Village government, Kolongan Tetempangan, 2019

Table 3.3. Natural Resources, Featured Koltem Village

\begin{tabular}{|c|c|l|}
\hline Number & Results & \multicolumn{1}{c|}{ Usability } \\
\hline 1 & Corn & $\begin{array}{l}\text { Animal feed ingredients } \\
- \text { Personal consumption }\end{array}$ \\
\hline 2 & Yam & - Raw material for home industry \\
\hline
\end{tabular}




\begin{tabular}{|c|c|l|}
\hline & & - Personal consumption \\
\hline 3 & Vegetables & $\begin{array}{l}- \text { Raw materials for home industries } \\
- \text { Personal consumption }\end{array}$ \\
\hline 4 & Spices & $\begin{array}{l}- \text { Raw meterials for home industries } \\
- \text { Personal consumption }\end{array}$ \\
\hline 5 & Coconut & $\begin{array}{l}- \text { Bahan baku pabrik } \\
- \text { Raw meterials for home industries } \\
- \text { Personal consumption }\end{array}$ \\
\hline 6 & Bananas & $\begin{array}{l}- \text { Raw meterials for home industries } \\
- \text { Personal consumption }\end{array}$ \\
\hline 7 & Papaya & $\begin{array}{l}- \text { Raw meterials for home industries } \\
- \text { Personal consumption }\end{array}$ \\
\hline 8 & Poultry (Chickens, Ducks) & $\begin{array}{l}- \text { Raw meterials for home industries } \\
- \text { Personal consumption }\end{array}$ \\
\hline 9 & Livestock Fish (Tilapia) & $\begin{array}{l}- \text { Raw meterials for home industries } \\
- \text { Personal consumption }\end{array}$ \\
\hline 10 & Animal Livestock (Pigs) & $\begin{array}{l}- \text { Raw meterials for home industries } \\
- \text { Personal consumption }\end{array}$ \\
\hline
\end{tabular}

Data Sources: Survey \& Interview, 2019

Table 3.4. Programs / Activities Funded by the Village Fund in Koltem Village

\begin{tabular}{|c|c|c|c|}
\hline \multirow{2}{*}{$\begin{array}{c}\text { Numb } \\
\text { er }\end{array}$} & \multirow{2}{*}{ Programs / Activities } & \multicolumn{2}{|c|}{ Implementation } \\
\hline & & Already & Not Yet \\
\hline 1 & $\begin{array}{l}\text { IMPLEMENTATION OF VILLAGE DEVELOPMENT WITH SOLID } \\
\text { PATTERNS OF CASH WORKS }\end{array}$ & $\sqrt{ }$ & \\
\hline 2 & PREVENTION OF Dwarfed Children & $\sqrt{ }$ & \\
\hline 3 & SAFE FOOD IN THE VILLAGE & $\sqrt{ }$ & \\
\hline 4 & EDUCATION SERVICES FOR CHILDREN & $\sqrt{ }$ & \\
\hline 5 & DEVELOPMENT OF FAMILY RESISTANCE & $\sqrt{ }$ & \\
\hline 6 & LEARNING AND TRAINING WORK & $\sqrt{ }$ & \\
\hline 7 & $\begin{array}{l}\text { DEVELOPMENT OF INCLUSION VILLAGE (Friendly village for } \\
\text { people with disabilities or people with disabilities) }\end{array}$ & & $\sqrt{ }$ \\
\hline 8 & $\begin{array}{l}\text { DEVELOPMENT OF VILLAGE LEADING PRODUCTS / RURAL } \\
\text { AREAS }\end{array}$ & & $\sqrt{ }$ \\
\hline 9 & $\begin{array}{l}\text { ESTABLISHMENT AND DEVELOPMENT OF VILLAGE } \\
\text { BUSINESS ENTITIES/ TOGETHER }\end{array}$ & $\sqrt{ }$ & \\
\hline 10 & DEVELOPMENT AND MANAGEMENT OF VILLAGE MARKETS & $\sqrt{ }$ & \\
\hline 11 & DEVELOPMENT OF INTEGRATED VILLAGE BUILDINGS & & $\sqrt{ }$ \\
\hline 12 & TOURISM DEVELOPMENT & & $\sqrt{ }$ \\
\hline 13 & $\begin{array}{l}\text { NATURAL RESOURCES LEARNING AND APPROPRIATE } \\
\text { TECHNOLOGY }\end{array}$ & $\sqrt{ }$ & \\
\hline 14 & $\begin{array}{l}\text { CONTROL OF CLIMATE CHANGE THROUGH MITIGATION AND } \\
\text { ADAPTATION }\end{array}$ & & $\sqrt{ }$ \\
\hline 15 & PREVENTION AND MANAGEMENT OF NATURAL DISASTERS & $\sqrt{ }$ & \\
\hline 16 & EMERGENCY RESPONSE TO NATURAL DISASTER RESPONSE & & $\sqrt{ }$ \\
\hline 17 & VILLAGE INFORMATION SYSTEMS & $\sqrt{ }$ & \\
\hline 18 & $\begin{array}{l}\text { DEVELOPMENT OF DISCLOSURE OF VILLAGE DEVELOPMENT } \\
\text { INFORMATION }\end{array}$ & $\sqrt{ }$ & \\
\hline 19 & LAW EMPOWERMENT IN THE VILLAGE & $\sqrt{ }$ & \\
\hline
\end{tabular}

Data Sources: Survey \& Interview, 2019

3.2. Priority Arrangement on the Use of Village Funds In Accordance with Village Minister Regulation Number 16 Year 2018

Tabel 3.5. Kriteria Tujuan \& Prinsip Table 3.5. Criteria Objectives \& Principles 


\begin{tabular}{|c|c|c|c|c|c|}
\hline \multirow[b]{2}{*}{$\begin{array}{c}\text { Num } \\
\text { ber }\end{array}$} & \multirow[b]{2}{*}{ Sub Criteria } & \multicolumn{3}{|c|}{ Number of Answers } & \multirow[b]{2}{*}{ Information } \\
\hline & & Yes & No & $\begin{array}{l}\text { Not } \\
\text { answe } \\
\text { ring }\end{array}$ & \\
\hline 1 & $\begin{array}{l}\text { Are there rules in setting priorities for the use of } \\
\text { village funds as a reference? }\end{array}$ & 5 & - & - & $\begin{array}{l}\text { The correct } \\
\text { answer is } \\
\text { 'yes' }\end{array}$ \\
\hline 2 & $\begin{array}{l}\text { Does determining the use of village funds prioritize the } \\
\text { rights and interests of all villagers without } \\
\text { discrimination? }\end{array}$ & 5 & - & - & $\begin{array}{l}\text { The correct } \\
\text { answer is } \\
\text { 'yes' }\end{array}$ \\
\hline 3 & $\begin{array}{l}\text { In determining the priority for the use of village funds, } \\
\text { prioritizes the interests of villages that are more urgent, } \\
\text { more needed, and directly related to the interests of the } \\
\text { majority of village communities? }\end{array}$ & 5 & - & - & $\begin{array}{l}\text { The correct } \\
\text { answer is } \\
\text { 'yes' }\end{array}$ \\
\hline 4 & $\begin{array}{l}\text { s determining the priority in the use of village funds, } \\
\text { prioritizing the choice of using village funds, in three } \\
\text { to five types of activities, according to national needs } \\
\text { and priorities, provincial areas, district / city and } \\
\text { village areas, and no practice of using village funds, } \\
\text { which is shared equally? }\end{array}$ & 5 & - & - & $\begin{array}{l}\text { The correct } \\
\text { answer is } \\
\text { 'yes' }\end{array}$ \\
\hline 5 & $\begin{array}{l}\text { Does determining priorities in the use of village funds } \\
\text { prioritize the authority of origin rights and local-scale } \\
\text { local authority? }\end{array}$ & 5 & - & - & $\begin{array}{l}\text { The correct } \\
\text { answer is } \\
\text { 'yes' }\end{array}$ \\
\hline 6 & $\begin{array}{l}\text { Does determining priorities in using village funds } \\
\text { prioritize village initiative, creativity, role and } \\
\text { community? }\end{array}$ & 4 & 1 & - & $\begin{array}{l}\text { The correct } \\
\text { answer is } \\
\text { 'yes' }\end{array}$ \\
\hline 7 & $\begin{array}{l}\text { Does determining the priority in the use of village } \\
\text { funds prioritize village independence in in } 50 \text { iting } \\
\text { village development activities funded by vi }\end{array}$ & 4 & - & 1 & $\begin{array}{l}\text { The correct } \\
\text { answer is } \\
\text { 'yes' }\end{array}$ \\
\hline 8 & $\begin{array}{l}\text { Does determining the priority in the use of village } \\
\text { funds prioritize the use of village funds, by utilizing } \\
\text { village resources, to finance development activities } \\
\text { that are managed and for village communities, so that } \\
\text { village funds revolve in a sustainable manner in the } \\
\text { village and / or district / city areas? }\end{array}$ & 4 & - & 1 & $\begin{array}{l}\text { The correct } \\
\text { answer is } \\
\text { 'yes' }\end{array}$ \\
\hline 9 & $\begin{array}{l}\text { Does determining priorities in the use of village funds } \\
\text { prioritize the utilization of human resources and } \\
\text { natural resources in the village in the implementation } \\
\text { of development funded by village funds? }\end{array}$ & 4 & 1 & - & $\begin{array}{l}\text { The correct } \\
\text { answer is } \\
\text { 'yes' }\end{array}$ \\
\hline 10 & $\begin{array}{l}\text { Does determining the priority in the use of village } \\
\text { funds take into account the specific geographical, } \\
\text { sociological, anthropological, economic and ecological } \\
\text { conditions and reality of the village, as well as } \\
\text { changes, or village development and progress? }\end{array}$ & 4 & 1 & - & $\begin{array}{l}\text { The correct } \\
\text { answer is } \\
\text { 'yes' }\end{array}$ \\
\hline & Amount & 45 & 3 & 2 & \\
\hline
\end{tabular}

Source: Processed Data (2019)

Priority Criteria for Using Village Funds

\begin{tabular}{|c|c|c|c|c|c|}
\hline \multirow[b]{2}{*}{$\begin{array}{c}\text { Num } \\
\text { ber }\end{array}$} & \multirow[b]{2}{*}{ Sub Criteria } & \multicolumn{3}{|c|}{ Number of Answers } & \multirow[b]{2}{*}{ Information } \\
\hline & & Yes & No & $\begin{array}{l}\text { Not } \\
\text { Answe } \\
\text { ring }\end{array}$ & \\
\hline 1 & $\begin{array}{l}\text { Is the use of village funds prioritized to finance the } \\
\text { implementation of programs and activities in the field } \\
\text { of village development? }\end{array}$ & 5 & - & - & $\begin{array}{l}\text { The correct } \\
\text { answer is } \\
\text { 'yes' }\end{array}$ \\
\hline 2 & Is the use of village funds prioritized to finance the & 5 & - & - & The correct \\
\hline
\end{tabular}




\begin{tabular}{|c|c|c|c|c|c|}
\hline & $\begin{array}{l}\text { implementation of programs and activities in the field } \\
\text { of village community empowerment? }\end{array}$ & & & & $\begin{array}{c}\text { answer is } \\
\text { 'yes' }\end{array}$ \\
\hline 3 & $\begin{array}{l}\text { Are priorities used by village funds to finance program } \\
\text { implementation and priority activities that are cross } \\
\text { sectoral? }\end{array}$ & 5 & - & - & $\begin{array}{l}\text { The correct } \\
\text { answer is } \\
\text { 'yes' }\end{array}$ \\
\hline 4 & $\begin{array}{l}\text { Is the priority of using village funds expected to } \\
\text { provide maximum benefits to village communities, in } \\
\text { the form of improving the quality of life, improving } \\
\text { welfare and poverty alleviation, and improving public } \\
\text { services at the village level? }\end{array}$ & 5 & - & - & $\begin{array}{l}\text { The correct } \\
\text { answer is } \\
\text { 'yes' }\end{array}$ \\
\hline 5 & $\begin{array}{l}\text { Is the village government obliged to publish priorities } \\
\text { in the use of village funds in the field of village } \\
\text { development and empowering village communities for } \\
\text { village communities in public spaces that can be } \\
\text { accessed by villagers? }\end{array}$ & 5 & - & - & $\begin{array}{l}\text { The correct } \\
\text { answer is } \\
\text { 'yes' }\end{array}$ \\
\hline 6 & $\begin{array}{l}\text { Is the publication of the use of village funds in a self- } \\
\text { managed and participatory manner involving the role } \\
\text { of the village community? }\end{array}$ & 4 & 1 & - & $\begin{array}{l}\text { The correct } \\
\text { answer is } \\
\text { 'yes' }\end{array}$ \\
\hline 7 & $\begin{array}{l}\text { In the case of villages, does not publicize the use of } \\
\text { village funds in public spaces, Regency / City } \\
\text { Governments impose administrative sanctions, in } \\
\text { accordance with statutory provisions? }\end{array}$ & 4 & - & 1 & $\begin{array}{l}\text { The correct } \\
\text { answer is } \\
\text { 'yes' }\end{array}$ \\
\hline \multicolumn{2}{|c|}{ 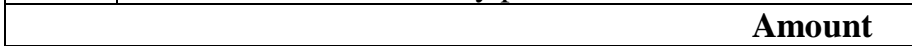 } & 33 & 1 & 1 & \\
\hline
\end{tabular}

Source: Processed Data (2019)

Table 3.7. Criteria for Prioritizing Mechanisms for the Use of Village Funds

\begin{tabular}{|c|l|c|c|c|c|}
\hline \multirow{2}{*}{$\begin{array}{c}\text { Num } \\
\text { ber }\end{array}$} & \multicolumn{1}{|c|}{ Sub Criteria } & Number of Answers & \multirow{2}{*}{$\begin{array}{c}\text { Not } \\
\text { Answe } \\
\text { ring }\end{array}$} & Information \\
\cline { 3 - 5 } & $\begin{array}{l}\text { Is the priority setting for the use of village funds in } \\
\text { accordance with village development planning } \\
\text { procedures carried out based on village authority? }\end{array}$ & 5 & - & - & $\begin{array}{c}\text { The correct } \\
\text { answer is 'ya' }\end{array}$ \\
\hline 2 & $\begin{array}{l}\text { Does the village authority as referred to in question } \\
\text { number 1 above, consist of village authority based on } \\
\text { origin rights and local scale village authority, which is } \\
\text { determined in accordance with statutory provisions? }\end{array}$ & 4 & - & 1 & $\begin{array}{c}\text { The correct } \\
\text { answer is } \\
\text { 'yes' }\end{array}$ \\
\hline 3 & $\begin{array}{l}\text { Is the determination of priorities for the use of village } \\
\text { funds, carried out in the preparation of the Village } \\
\text { Government Work Plan? }\end{array}$ & 4 & - & 1 & $\begin{array}{c}\text { The correct } \\
\text { answer is } \\
\text { 'yes' }\end{array}$ \\
\hline 5 & $\begin{array}{l}\text { Is the determination of priorities for the use of village } \\
\text { funds, carried out in an integrated manner with } \\
\text { national, provincial and regional development planning } \\
\text { and district / city area? }\end{array}$ & 5 & - & - & $\begin{array}{c}\text { The correct } \\
\text { answer is } \\
\text { 'yes' }\end{array}$ \\
\hline 5 & $\begin{array}{l}\text { Is the integration of national, provincial, and district / } \\
\text { city development plans, as referred to in question } \\
\text { number 4 above carried out by the Regency / City } \\
\text { Government, and the Regency / City Government } \\
\text { informing the village? }\end{array}$ & 4 & - & 1 & $\begin{array}{c}\text { The correct } \\
\text { answer is } \\
\text { 'yes' }\end{array}$ \\
\hline 6 & $\begin{array}{l}\text { Regarding question number 5, what is informed by the } \\
\text { Regency / City Government to the village, which is the } \\
\text { indicative ceiling for village funds as a basis for the } \\
\text { preparation of the Village Government Work Plan, } \\
\text { and village development programs / activities funded } \\
\text { by the Revenue Budget and Regional Expenditures } \\
\text { Regency / City, Province and / or Revenue Budget and } \\
\text { State Shopping? }\end{array}$ & 4 & 1 & - & $\begin{array}{l}\text { The correct } \\
\text { answer is } \\
\text { 'yes' }\end{array}$ \\
\hline
\end{tabular}




\begin{tabular}{|c|c|c|c|c|c|}
\hline 7 & $\begin{array}{l}\text { What is the priority of the use of village funds that are } \\
\text { set as priority activities, budget } \\
\text { and village expenditure must be discussed } \\
\text { and agreed through the Village Deliberation? }\end{array}$ & 5 & - & - & $\begin{array}{l}\text { The correct } \\
\text { answer is } \\
\text { 'yes' }\end{array}$ \\
\hline 8 & $\begin{array}{l}\mathrm{f} \text { the priority for using village funds as a priority for } \\
\text { activities, the village budget and expenditure must be } \\
\text { discussed } \\
\text { and agreed through the Village Deliberation, is the } \\
\text { result of the Village Deliberation decision the basis for } \\
\text { the preparation of the Village Government Work Plan? }\end{array}$ & 5 & - & - & $\begin{array}{l}\text { The correct } \\
\text { answer is } \\
\text { 'yes' }\end{array}$ \\
\hline 9 & $\begin{array}{l}\text { Is the priority of development activities financed by } \\
\text { village funds that have been determined in the Village } \\
\text { Government Work Plan must be guided in the } \\
\text { preparation of the Revenue Budget and Village } \\
\text { Expenditures as outlined in the Draft Budget and } \\
\text { Village Shopping? }\end{array}$ & 4 & - & 1 & $\begin{array}{l}\text { The correct } \\
\text { answer is } \\
\text { 'yes' }\end{array}$ \\
\hline 10 & $\begin{array}{l}\text { What is the Revenue Budget Plan and Village } \\
\text { Expenditures as referred to in question number } 9 \text { above } \\
\text { are evaluated by the Regent / Mayor? }\end{array}$ & 4 & - & 1 & $\begin{array}{l}\text { The correct } \\
\text { answer is } \\
\text { 'yes' }\end{array}$ \\
\hline 11 & $\begin{array}{l}\mathrm{f} \text { the Draft Budget Revenue } \\
\text { and Village expenditures are evaluated by the Regent / } \\
\text { Mayor and find out the plan for using the village funds } \\
\text { contained in the Draft Budget and Village } \\
\text { Expenditures are declared not in accordance with } \\
\text { public interest and higher laws and regulations, } \\
\text { whether the regent / mayor provided a written } \\
\text { explanation to the village about his background and the } \\
\text { reasons for disagreement over the planned use of the } \\
\text { village fund? }\end{array}$ & 4 & - & 1 & $\begin{array}{l}\text { The correct } \\
\text { answer is } \\
\text { 'yes' }\end{array}$ \\
\hline 12 & $\begin{array}{l}\text { If there is a disagreement over the planned use of } \\
\text { village funds, as referred to in question number } 11 \\
\text { above, does the Village Head convey it to the village } \\
\text { community through Regional Requirement Board in } \\
\text { Village Deliberation? }\end{array}$ & 4 & 1 & - & $\begin{array}{l}\text { The correct } \\
\text { answer is } \\
\text { 'yes' }\end{array}$ \\
\hline 13 & $\begin{array}{l}\text { In the case of mapping village typologies based on the } \\
\text { level of village development, in order to prioritize the } \\
\text { use of village funds, does the Village Government use } \\
\text { the Village Build Index data? }\end{array}$ & 3 & - & 2 & $\begin{array}{l}\text { The correct } \\
\text { answer is } \\
\text { 'yes' }\end{array}$ \\
\hline 14 & $\begin{array}{l}\text { Do district / city governments evaluate the level of } \\
\text { village development based on IDM data? }\end{array}$ & 3 & 1 & 1 & $\begin{array}{l}\text { The correct } \\
\text { answer is } \\
\text { 'yes' }\end{array}$ \\
\hline 15 & $\begin{array}{l}\text { Are the results of the evaluation of the level of village } \\
\text { development, as referred to in question number } 14 \\
\text { above, completed at the latest before the start of the } \\
\text { preparation of the Village Government Work Plan for } \\
\text { the Year? }\end{array}$ & 3 & 1 & 1 & $\begin{array}{l}\text { The correct } \\
\text { answer is } \\
\text { 'yes' }\end{array}$ \\
\hline 16 & $\begin{array}{l}\text { Do the results of evaluating the level of village } \\
\text { development, as referred to in question number } 15 \\
\text { above, be openly informed by the Regency / City } \\
\text { Government? }\end{array}$ & 3 & 1 & 1 & $\begin{array}{l}\text { The correct } \\
\text { answer is } \\
\text { 'yes' }\end{array}$ \\
\hline 17 & $\begin{array}{l}\text { Do the evaluation results referred to in question } \\
\text { number } 16 \text { above become a reference in the } \\
\text { preparation of the Technical Guidelines for the Use of } \\
\text { Village Funds? }\end{array}$ & 3 & 1 & 1 & $\begin{array}{l}\text { The correct } \\
\text { answer is } \\
\text { 'yes' }\end{array}$ \\
\hline \multicolumn{2}{|r|}{ Amount } & 67 & 6 & 12 & \\
\hline
\end{tabular}

Source: Processed Data (2019) 
Table 3.8. Guidance and Supervision Criteria

\begin{tabular}{|c|c|c|c|c|c|}
\hline \multirow[b]{2}{*}{$\begin{array}{c}\text { Num } \\
\text { ber }\end{array}$} & \multirow[b]{2}{*}{ Sub Criteria } & \multicolumn{3}{|c|}{ Number of Answers } & \multirow[b]{2}{*}{ Information } \\
\hline & & Yes & No & $\begin{array}{l}\text { Not } \\
\text { Answe } \\
\text { ring }\end{array}$ & \\
\hline 1 & $\begin{array}{l}\text { Are the development activities and supervision of the } \\
\text { implementation of priority setting for the use of village } \\
\text { funds nationally carried out by the Minister? }\end{array}$ & 4 & - & 1 & $\begin{array}{l}\text { The correct } \\
\text { answer is } \\
\text { 'yes' }\end{array}$ \\
\hline 2 & $\begin{array}{l}\text { Does the coaching activity as referred to in question } \\
\text { number } 1 \text { above cover the provision of guidelines, } \\
\text { standards, facilitation and technical guidance, as well } \\
\text { as monitoring and evaluation? }\end{array}$ & 4 & - & 1 & $\begin{array}{l}\text { The correct } \\
\text { answer is } \\
\text { 'yes' }\end{array}$ \\
\hline 3 & $\begin{array}{l}\text { Are the monitoring activities referred to in question } \\
\text { number } 1 \text { above carried out to achieve effectiveness, } \\
\text { and material for formulating policy for Priority Use of } \\
\text { village funds? }\end{array}$ & 4 & - & 1 & $\begin{array}{l}\text { The correct } \\
\text { answer is } \\
\text { 'yes' }\end{array}$ \\
\hline 4 & $\begin{array}{l}\text { In implementing the priority use of village funds, the } \\
\text { Minister through the Echelon-I Officer who handles } \\
\text { the field of development, and empowering the village } \\
\text { community, conducts supervision in accordance with } \\
\text { statutory provisions? }\end{array}$ & 4 & - & 1 & $\begin{array}{l}\text { The correct } \\
\text { answer is } \\
\text { 'yes' }\end{array}$ \\
\hline 5 & $\begin{array}{l}\text { Is the supervision activity in the form of monitoring } \\
\text { and evaluation in the context of using priority district / } \\
\text { city village funds carried out by the Governor, as the } \\
\text { central representative in the regions? }\end{array}$ & 4 & - & 1 & $\begin{array}{l}\text { The correct } \\
\text { answer is } \\
\text { 'yes' }\end{array}$ \\
\hline 6 & $\begin{array}{l}\text { Are the activities of monitoring and evaluating the use } \\
\text { of priority village funds carried out by the Regent / } \\
\text { Mayor? }\end{array}$ & 4 & - & 1 & $\begin{array}{l}\text { The correct } \\
\text { answer is } \\
\text { 'yes' }\end{array}$ \\
\hline 7 & $\begin{array}{l}\text { Can the monitoring and evaluation of the use of village } \\
\text { funds referred to in question number } 6 \text { above be } \\
\text { delegated to the Regional Apparatus Organization? } \\
\text { in charge of government affairs in the field of } \\
\text { Community and Village Empowerment? }\end{array}$ & 4 & - & 1 & $\begin{array}{l}\text { The correct } \\
\text { answer is } \\
\text { 'yes' }\end{array}$ \\
\hline 8 & $\begin{array}{l}\text { In the context of monitoring and evaluation as referred } \\
\text { to in question number } 6 \text { above, does the district / city } \\
\text { government provide assistance and facilitation to } \\
\text { villages assisted by professional advisors? }\end{array}$ & 4 & - & 1 & $\begin{array}{l}\text { The correct } \\
\text { answer is } \\
\text { 'yes' }\end{array}$ \\
\hline 9 & $\begin{array}{l}\text { Can the evaluation of the results of monitoring and } \\
\text { evaluation as referred to in question number } 7 \text { above } \\
\text { be carried out by the competent Regional Apparatus } \\
\text { Organization, and submitted to the Regent and } \\
\text { Minister through a reporting system in accordance with } \\
\text { statutory provisions? }\end{array}$ & 4 & - & 1 & $\begin{array}{l}\text { The correct } \\
\text { answer is } \\
\text { 'yes' }\end{array}$ \\
\hline 10 & $\begin{array}{l}\text { Are the tasks of guidance and supervision in setting } \\
\text { priorities for the use of village funds through the } \\
\text { facilitation of participatory development planning and } \\
\text { village community empowerment programs carried out } \\
\text { by the Camat or other designations? }\end{array}$ & 4 & - & 1 & $\begin{array}{l}\text { The correct } \\
\text { answer is } \\
\text { 'yes' }\end{array}$ \\
\hline & Amount & 40 & - & 10 & \\
\hline
\end{tabular}

Source: Processed Data (2019)

Table 3.9. Reporting Criteria

\begin{tabular}{|c|c|c|c|c|c|}
\hline \multirow{2}{*}{$\begin{array}{c}\text { Num } \\
\text { ber }\end{array}$} & Sub Criteria & \multicolumn{3}{|c|}{ Number of Answers } & Not \\
\end{tabular}




\begin{tabular}{|c|c|c|c|c|c|}
\hline & & & & ring & \\
\hline 1 & $\begin{array}{l}\text { s the report on the determination of priorities for the } \\
\text { use of village funds, accompanied by softcopy of } \\
\text { working papers calculating village funds for each } \\
\text { village to the Minister c.q. Director General of } \\
\text { Development and Empowerment of Village } \\
\text { Communities, and delivered by the Regent / Mayor? }\end{array}$ & 3 & - & 2 & $\begin{array}{l}\text { The correct } \\
\text { answer is } \\
\text { 'yes' }\end{array}$ \\
\hline 2 & $\begin{array}{l}\text { Is the report on determining the priority for the use of } \\
\text { village funds, as referred to in question number } 1 \\
\text { above, prepared in accordance with the format listed in } \\
\text { Annex III of the Ministerial Regulation? }\end{array}$ & 3 & - & 2 & $\begin{array}{l}\text { The correct } \\
\text { answer is } \\
\text { 'yes' }\end{array}$ \\
\hline 3 & $\begin{array}{l}\mathrm{s} \text { the submission of the report referred to in question } \\
\text { number } 1 \text { above, done no later than } 1 \text { month after the } \\
\text { Revenue Budget and } \\
\text { Village spending is set? }\end{array}$ & 3 & - & 2 & $\begin{array}{l}\text { The correct } \\
\text { answer is } \\
\text { 'yes' }\end{array}$ \\
\hline \multicolumn{2}{|c|}{ Amount } & 9 & - & 6 & \\
\hline
\end{tabular}

Source: Processed Data (2019)

Table 3.10. Criteria for Community Participation

\begin{tabular}{|c|c|c|c|c|c|}
\hline \multirow[b]{2}{*}{$\begin{array}{c}\text { Num } \\
\text { ber }\end{array}$} & \multirow[b]{2}{*}{ Sub Criteria } & \multicolumn{3}{|c|}{ Number of Answers } & \multirow[b]{2}{*}{ Information } \\
\hline & & Yes & No & $\begin{array}{c}\text { Not } \\
\text { Answe } \\
\text { ring }\end{array}$ & \\
\hline 1 & $\begin{array}{l}\text { Can the community participate in, and monitor and } \\
\text { oversee the determination of priorities for the use of } \\
\text { village funds that are accountable and transparent, by } \\
\text { submitting complaints about the determination of } \\
\text { priorities for the use of village funds? }\end{array}$ & 5 & - & - & $\begin{array}{l}\text { The correct } \\
\text { answer is } \\
\text { 'yes' }\end{array}$ \\
\hline 2 & $\begin{array}{l}\text { Can the community participate in monitoring and } \\
\text { overseeing the determination of priorities for } \\
\text { accountable and transparent village funds by providing } \\
\text { assistance to villages in setting priorities for the use of } \\
\text { village funds, in accordance with statutory provisions? }\end{array}$ & 4 & 1 & - & $\begin{array}{l}\text { The correct } \\
\text { answer is } \\
\text { 'yes' }\end{array}$ \\
\hline 3 & $\begin{array}{l}\text { Can the community participate in and monitor and } \\
\text { supervise the prioritization of accountable and } \\
\text { transparent use of village funds by conducting studies } \\
\text { and publication of the priority application of village } \\
\text { funds? }\end{array}$ & 4 & 1 & - & $\begin{array}{l}\text { The correct } \\
\text { answer is } \\
\text { 'yes' }\end{array}$ \\
\hline 4 & $\begin{array}{l}\text { Can complaints regarding the determination of } \\
\text { priorities for using village funds be made through the } \\
\text { Information Management Officer, } \\
\text { and Documentation at the Ministry of Villages, } \\
\text { Disadvantaged Regions, and Transmigration with } \\
\text { complaint address: Telephone services: } 1500040 \text {, SMS } \\
\text { Center Services: 087788990040, 081288990040, } \\
\text { Information Management Officer Services, } \\
\text { and Documentation: Main Building 1st Floor, Bureau } \\
\text { of Public Relations and Cooperation, Social Media } \\
\text { Services: @ Kendendesa (twitter), Kemendesa.1 } \\
\text { (Facebook) and the LAPOR website of the Presidential } \\
\text { Staff Office? }\end{array}$ & 4 & - & 1 & $\begin{array}{l}\text { The correct } \\
\text { answer is } \\
\text { 'yes' }\end{array}$ \\
\hline & Amount & 17 & 2 & 1 & \\
\hline
\end{tabular}

Source: Processed Data (2019)

Table 3.11. Sanction Criteria 


\begin{tabular}{|c|l|c|c|c|c|}
\hline \multirow{2}{*}{$\begin{array}{c}\text { Num } \\
\text { ber }\end{array}$} & \multicolumn{1}{|c|}{ Sub Criteria } & Yes & No & $\begin{array}{c}\text { Not } \\
\text { Answe } \\
\text { r } \\
\text { Ing }\end{array}$ & Information \\
\cline { 2 - 5 } & $\begin{array}{l}\text { Are the Regional Apparatus Organizations that do not } \\
\text { carry out monitoring and evaluation of the priority use } \\
\text { of village funds may be subject to sanctions in } \\
\text { accordance with statutory regulations, in the form of a } \\
\text { written warning and recommen delaying the } \\
\text { distribution of village funds to the Minister of } \\
\text { Finance? }\end{array}$ & 4 & - & 1 & $\begin{array}{c}\text { The correct } \\
\text { answer is } \\
\text { 'yes' }\end{array}$ \\
\hline 2 & $\begin{array}{l}\text { Imposition of sanctions as referred to in question } \\
\text { number 1 above } \\
\text { Is it freeing the regency / city regional apparatus } \\
\text { organization from the obligation to submit priority } \\
\text { setting report on the use of village funds? }\end{array}$ & 1 & 3 & 1 & $\begin{array}{l}\text { The correct } \\
\text { answer is } \\
\text { 'No' }\end{array}$ \\
\hline
\end{tabular}

Source: Processed Data (2019)

Based on the results of the answers given, the level of accuracy of the answers given is summarized in the following table.

Table 3.12. Questionnaire Results

\begin{tabular}{|c|l|c|c|c|c|}
\hline \multirow{3}{*}{ Number } & \multicolumn{4}{|c|}{ Results } \\
\cline { 3 - 6 } & \multicolumn{1}{|c|}{ Question Criteria } & $\begin{array}{c}\text { Number of } \\
\text { Sub } \\
\text { Criteria }\end{array}$ & $\begin{array}{c}\text { Questionnaire } \\
\text { Number }\end{array}$ & $\begin{array}{c}\text { Number of Correct } \\
\text { Answers }\end{array}$ \\
\cline { 3 - 6 } & & 10 & 50 & 45 & Q \\
\hline 1 & Objectives \& Principles & 7 & 35 & 33 & 94,29 \\
\hline 2 & Priority Use of Village Funds & 17 & 85 & 67 & 78,82 \\
\hline 3 & $\begin{array}{l}\text { Mechanism of Determining Priority in the } \\
\text { Use of Village Funds }\end{array}$ & 10 & 50 & 40 & 80 \\
\hline 4 & Guidance and supervision & 3 & 15 & 9 & 60 \\
\hline 5 & Reporting & 4 & 20 & 17 & 85 \\
\hline 6 & Society participation & 2 & 10 & 7 & 70 \\
\hline 7 & Penalty & & & & \\
\hline
\end{tabular}

Source: Processed Data (2019)

\section{Information :}

* Number of respondents $=5$ People

* Number of question criteria $=7$ Criteria

* Jumlah sub kriteria pertanyaan $=53$ Sub Criteria

* Number of questionnaires = Number of respondents $\mathrm{x}$ Number of sub-criteria questions

* Correct answer criteria: :

- $<50 \% \quad$ (Not According)

- $50 \%-100 \%$ (according)

\subsection{Evaluasi Tingkat Efektivitas dan Efisiensi Pengelolaan Dana Desa (DD) Sesuai Permendes Nomor 16 Tahun 2018}

The village fund assistance program began rolling nationally, and distributed to all villages in remote parts of Indonesia since 2015. However, for the government and the people in Kolongan Tetempangan Village, the program only began to be obtained and felt in 2016. The data on the amount of village fund assistance received during 2016 until 2018, can be seen in the following table.

Table 3.13. Budget, Realization of the Acceptance and Use of Village Funds 


\begin{tabular}{|c|c|c|c|c|}
\hline Number & Year & Budget (Target) & $\begin{array}{c}\text { Realization of } \\
\text { Revenue }\end{array}$ & $\begin{array}{c}\text { Realization of Use } \\
\text { (Shopping) }\end{array}$ \\
\hline 1 & 2016 & IDR 611.585.000 & IDR 611.585.000 & IDR 571.585.000 \\
\hline 2 & 2017 & IDR 782.941.161 & IDR 469.764.697 & IDR 469.764.697 \\
\hline 3 & 2018 & IDR 693.994.000 & IDR 693.994.000 & IDR 693.994.000 \\
\hline
\end{tabular}

Source: Kolongan Tetempangan village government (2019)

Based on information obtained, namely regarding village funds. Furthermore, the research team used these data to measure the effectiveness of the management of the financial assistance provided. The calculation of the level of effectiveness of the receipt of village funds applicable in the village of Kolongan - Tetempangan, illustrates the maximum realization of the receipt of village funds, from a plan determined based on the authority possessed by the village, such as authority based on original rights and village-scale local authority. This means that the higher the effectiveness ratio shows that the village's ability to run programs and activities that are more optimal. But this will be different if the opposite occurs.

Table 3.14. Effectiveness of Village Fund Management in Kolongan-Tetempangan Village

\begin{tabular}{|c|c|c|c|c|}
\hline Year & $\begin{array}{c}\text { Budget } \\
\text { (Target) }\end{array}$ & $\begin{array}{c}\text { Realization of } \\
\text { Revenue }\end{array}$ & $\begin{array}{c}\text { Effectiveness } \\
\text { Ratio }\end{array}$ & Information \\
\hline 2016 & Rp 611.585.000 & IDR 611.585.000 & $100 \%$ & Effective \\
\hline 2017 & Rp 782.941.161 & IDR 469.764.697 & $60 \%$ & Less effective \\
\hline 2018 & Rp 693.994.000 & IDR 693.994.000 & $100 \%$ & Effective \\
\hline
\end{tabular}

\section{Source: Processed Data (2019)}

Based on the data presented in the table above, the research team summarized the results of calculations to determine the ratio of effectiveness. The first column lists the fiscal year, which starts from 2016 to 2018. Whereas the second column and third, includes a revenue budget that contains a large amount of the village fund budget that has been determined the amount of the realization of village funds received for each year. The data shows that the potential of Kolongan-Tetempangan Village in managing village funds is in the range of 86.67 percent and for these conditions, it was declared effective because it was able to absorb almost all of the predetermined budget plans.

Furthermore, based on information obtained from the village funds, the research team used the data obtained to measure the level of efficiency in the use of the funds. The measurement of the ratio of the level of efficiency of the use of village fund assistance that occurred in the village of Kolongan-Tetempangan, namely through measuring the comparison between the realization of the use of village funds and the realization of village fund receipts. The size of the ratio is declared efficient, if the size of the ratio gets smaller and this is different if the opposite applies.

Table 3.15. Efficiency of Village Fund Management in Kolongan-Tetempangan Village

\begin{tabular}{|c|c|c|c|c|}
\hline Year & $\begin{array}{c}\text { Realization of } \\
\text { Revenue }\end{array}$ & $\begin{array}{c}\text { Realization of Use } \\
\text { (Shopping) }\end{array}$ & $\begin{array}{c}\text { Efficiency } \\
\text { Ratio }\end{array}$ & Information \\
\hline 2016 & IDR 611.585 .000 & IDR 571.585 .000 & $93,46 \%$ & Less effective \\
\hline 2017 & IDR 469.764.697 & IDR 469.764.697 & $100 \%$ & Effective \\
\hline
\end{tabular}




\begin{tabular}{|l|c|c|c|c|}
\hline 2018 & IDR 693.994.000 & IDR 693.994.000 & $100 \%$ & Effective \\
\hline
\end{tabular}

Source: Processed Data (2019)

Based on the processed data presented in the above table, it can be explained that the level of efficiency ratios that occur in the management of village funds in 2016, amounted to 93.46 percent. Then in 2017 and 2018 the calculation results are the same, which is 100 percent. Thus, overall the efficiency measure obtained in the management of village funds in the KolonganTetempangan Village for a period of 3 years, amounting to 97.82 percent and declared efficient.

Table 3.16. Priority Use of Village Funds in Kolongan-Tetempangan Village

\begin{tabular}{|c|c|c|c|c|c|}
\hline $\begin{array}{l}\text { Year } \\
\text { (1) }\end{array}$ & $\begin{array}{l}\text { Priority Use of Village } \\
\text { Funds } \\
(2)\end{array}$ & $\begin{array}{l}\text { Realization of } \\
\text { Revenue } \\
\text { (3) } I D R\end{array}$ & $\begin{array}{l}\text { Realization of } \\
\text { Use } \\
\text { (4) } I D R\end{array}$ & $\begin{array}{l}\text { Difference } \\
\text { (5) }\end{array}$ & $\begin{array}{l}\% \\
(6)\end{array}$ \\
\hline 2016 & $\begin{array}{l}\text { - Village Development } \\
\text { - Village Community } \\
\text { Empowerment }\end{array}$ & $\begin{array}{l}428.109 .500 \\
143.475 .500\end{array}$ & $\begin{array}{l}428.109 .500 \\
143.475 .500\end{array}$ & - & $\begin{array}{l}74,90 \% \\
25,10 \%\end{array}$ \\
\hline 2017 & $\begin{array}{l}\text { - Village Development } \\
\text { - Village Community } \\
\text { Empowerment }\end{array}$ & $\begin{array}{l}328.835 .288 \\
140.929 .409\end{array}$ & $\begin{array}{l}328.835 .288 \\
140.929 .409\end{array}$ & - & $\begin{array}{l}70 \% \\
30 \%\end{array}$ \\
\hline 2018 & $\begin{array}{l}\text { - Village Development } \\
\text { - Village Community } \\
\text { Empowerment }\end{array}$ & $\begin{array}{r}598.994 .000 \\
95.000 .000\end{array}$ & $\begin{array}{r}598.994 .000 \\
95.000 .000\end{array}$ & $\begin{array}{l}- \\
-\end{array}$ & $\begin{array}{l}86,31 \% \\
13,69 \%\end{array}$ \\
\hline
\end{tabular}

Source: Processed Data (2019)

Table 3.17. Evaluation of Priority Use of Village Funds in the Kolongan Tetempangan Village

\begin{tabular}{|c|l|c|c|}
\hline \multirow{2}{*}{$\begin{array}{c}\text { Num } \\
\text { ber }\end{array}$} & \multicolumn{1}{|c|}{ Criteria } & \multicolumn{2}{c|}{$\begin{array}{c}\text { Period } \\
\text { 2016 s/d 2018 }\end{array}$} \\
\cline { 3 - 4 } & & Corresponding & Not appropriate \\
\hline 1 & Purpose \& Principles & $\sqrt{ }$ & \\
\hline 2 & Priority for Using Village Funds & $\sqrt{ }$ & \\
\hline 3 & $\begin{array}{l}\text { Mechanisms for Determining Priority in Using } \\
\text { Village Funds }\end{array}$ & $\sqrt{ }$ & \\
\hline 4 & Guidance and Supervision & $\sqrt{ }$ & \\
\hline 5 & Reporting & $\sqrt{ }$ & \\
\hline 6 & Community Participation & $\sqrt{ }$ & \\
\hline 7 & Sanctions & & \\
\hline
\end{tabular}

Source: Processed Data (2019)

The evaluation results in the table above were obtained through field surveys, showing that the village government in Kolongan Tetempangan Village, between 2016 and 2018, was appropriate in managing village funds, based on the points contained in the regulations made by the government.

\section{CONCLUSION}

After the stages have been passed in this study, in the end we, the research team from the Department of Accounting, Manado State Polytechnic who conducted research on the Evaluation of the Effectiveness and Efficiency Level in Village Fund Management 
in accordance with Ministerial Regulation No. 16 of 2018 in the village of Kolongan Tetempangan obtained conclusions from this study. The conclusions obtained are as follows:

1) From the data obtained shows that during the period of 3 years (2016 to 2018), the management of village funds in Kolongan Tetempangan Village was effective because it was able to absorb almost all of the predetermined budget plans.

2) Based on the processed data presented, it shows that the village government in Kolongan Tetempangan Village is efficient in managing village funds, within 3 years (2016 to 2018).

3) In terms of prioritizing the use of village funds, the village government in Kolongan Tetempangan Village, is appropriate in carrying out its tasks and their responsibilities based on the applicable laws and regulations.

\section{REFERENCES}

Georgopolous dan Tannenbaum. 1985. Organizational Effectiveness.

Handayaningrat, Soewarno. 1994. Introduction to the Study of Administration and Management. Jakarta: Haji Masagung.

Masruri. 2014. Analysis of the Effectiveness of the National Program, Empowerment of Urban Independent Communities. Padang: Akademia Permata.

Musianto, L.S. 2002. Differences in Quantitative Approaches, and Qualitative Approaches in Research Methods. Jurnal Manajemen \& Kewirausahaan. Vol: 4.2.

Minister of Home Affairs Regulation Number 113 Year 2014, Regarding Guidelines for Village Financial Management.

Government Regulation of the Republic of Indonesia Number 60 of 2014 concerning Village Funds Sourced from the Revenue Budget and State Expenditures.

Government Regulation of the Republic of Indonesia, Number 8 of 2016 concerning Amendment, Second to Government Regulation of Number 60 of 2014, Regarding Village Funds Sourced from the Budget and State Expenditures

Government Regulation of the Republic of Indonesia Number 11 Year 2019, Regarding the Second Amendment to Government Regulation Number 43 of 2014, Regarding Regulation of the Implementation of Law Number 6 of 2014, Regarding Villages

Government Regulation of the Republic of Indonesia Number 43 of 2014, Regarding Regulations for the Implementation of Law Number 6 of 2014 concerning Villages.

Regulation of the Minister of Villages, Development of Disadvantaged Regions, and Transmigration of the Republic of Indonesia Number 16 Year 2018 Regarding Priority for the Use of Village Funds in 2019.

Sein Religi. 2018. Statistics of North Minahasa Regency. Badan Pusat Statistik Kabupaten Minahasa Utara.

Steers, Richard M. 1985. Effectiveness of Organizational Rules of Behavior, Jakarta: Erlangga.

Sugiyono. 2012. Understanding Qualitative Research, Bandung: Alfabeta.

Law of the Republic of Indonesia Number 6 of 2014 concerning Villages 